\title{
Functional capacity of adipose tissue in human obesity and hyperlipidaemia
}

\author{
By J. TREMOLIERES, Cl. SAUTIER, L. CARRE, \\ CL. FLAMENT AND B. PLUMAS \\ Laboratoire de Nutrition Humaine de l'INSERM, \\ Hôpital Bichat, Paris, France \\ (Received I I September 1973-Accepted 30 November 1973)
}

\begin{abstract}
I. Fifteen 'constitutionally' obese subjects, eleven hyperlipidaemic subjects of mixed-type and fourteen normal subjects were studied.

2. With a reduction in energy intake (range $3 \cdot 3-4 \cdot 2 \mathrm{MJ}$ ) for $2 \mathrm{I} \mathrm{d}$, there was no change in the levels of plasma total cholesterol (TC) and triglyceride (TG) of obese subjects, but the free fatty acid levels increased. However, in hyperlipidaemic subjects there was a reduction in levels of TC and TG with no increase in levels of free fatty acids.

3. There was a significant increase in the serum ketone levels of obese subjects but not in those of hyperlipidaemic subjects. The reduction of the respiratory quotient to a value of 0.7 was more rapid in the obese than in hyperlipidaemic subjects.

4. After administration of a fat load $(0.5 \mathrm{~g} / \mathrm{kg}$ gross body-weight) there was no change in plasma TG levels in obese subjects but there was an increase in those of normal subjects.

5. After administration of a glucose load ( $\mathrm{g} / \mathrm{kg}$ ideal body-weight) there was a significant reduction in plasma $T G$ levels in obese subjects but no change in those of hyperlipidaemic subjects.

6. Hyperlipidaemic subjects eating their normal diet were found to have a hydroxybutyrate: acetoacetate ratio three- to fivefold that of obese and normal subjects.

7. These results suggest that obese subjects have an increased ability to store fatty acids, to mobilize them quickly and to generate fatty acid metabolites in the form of ketone bodies, while these same metabolic functions are reduced in hyperlipidaemic subjects.
\end{abstract}

The main function of adipose tissue is the storage and redistribution of plasma fatty acids (FA). Their storage is one method of clearing lipoprotein from the plasma. Lipoprotein lipase activity and glycolysis to provide $\alpha$-glycerophosphate for reesterification in adipocytes, are the main regulators of this clearance system. The redistribution of $\mathrm{FA}$ is regulated through adipocyte hormone-sensitive lipase activity. Under conditions in which utilization of FA for oxidation and lipoprotein biosynthesis can be experimentally modified and controlled, i.e. reduction of energy intake, or triglyceride (TG) or glucose load, the functional capacity of adipose tissue is reflected in the variations of $\mathrm{FA}$ and their metabolites in the plasma.

There is no classification of human obesity based on metabolic or biochemical measurements. 'Constitutionally' or 'metabolically' obese subjects were defined as those maintaining a stable body-weight from $\mathrm{I}$ to 6 months with a diet (determined by interview) providing less than $20 \%$ energy above their basal metabolic rate (BMR). The total cholesterol (TC) levels in these subjects are low and the plasma TG are at the upper limit of the normality range.

The purpose of this work was to explain the functional capacity of adipose tissue in regulating FA and their metabolites in the plasma, comparing a group of 'constitutionally' obese (group I), to hyperlipidaemic subjects of mixed-type (group 2) 
and normal subjects (group 3 ). In each group, variations in total lipids (TL), TC, TG, free fatty acids (FFA), $\beta$-hydroxybutyrate $(\beta-\mathrm{HOB})$, acetoacetate (AcAc), lactate and pyruvate levels were examined after: $(a)$ a reduction in energy intake for $2 \mathrm{I} \mathrm{d}$ in groups I and $2 ;(b)$ a glucose load of $\mathrm{I} / \mathrm{kg}$ ideal body-weight in groups $\mathrm{I}$ and 2 and $(c)$ a triglyceride load of $0.5 \mathrm{~g} / \mathrm{kg}$ gross body-weight in groups $\mathrm{I}$ and 3 . We also measured respiratory exchanges to estimate the lipid: carbohydrate ratio in oxidation or lipogenesis.

\section{METHODS}

Normal group. Subjects were fourteen laboratory workers, average age 43 years (range $25-57$ ), average weight $64 \cdot 8 \mathrm{~kg}$ (range $5^{1}{ }^{-5}-82$ ) exceeding their ideal bodyweight (Geigy, 1959) by an average of $10 \%$ (range -2 to +14 ). Their normal diet, determined by interview, provided daily (mean \pm SD) $9.25 \pm 0.88 \mathrm{MJ} ; 86 \pm 5.1$ g protein; $89 \pm \mathbf{r} 3 \mathrm{~g}$ fat. On the day before administration of a glucose load, ten subjects (five male, five female) were given a diet providing (mean $\pm \mathrm{sD}$ ) 8.82 $\pm 0.64 \mathrm{MJ}$; $74 \pm 5.6 \mathrm{~g}$ protein; $74 \pm \mathrm{I} 2 \mathrm{~g}$ fat and before administration of the TG load, four male subjects received a diet providing (mean $\pm \mathrm{SD}$ ) $10.5 \pm 0.1 \mathrm{I} \mathrm{MJ} ; 99 \pm 17 \mathrm{~g}$ protein; $80 \pm 12 \cdot 7 \mathrm{~g}$ fat.

'Constitutionally' obese group. These were thirteen female and two male subjects, average age 35 years (range $18-51$ ). Their normal diet (by interview) provided daily $5.6 \pm 0.88 \mathrm{MJ} ; 66 \pm \mathrm{r} \cdot 9 \mathrm{~g}$ protein; $43 \pm 8.7 \mathrm{~g}$ fat. Their actual mean body-weight was $87 \mathrm{~kg}$ (range $8 \mathrm{I}-96$ ) exceeding their ideal body-weight (Geigy, 1959 ) by $51 \%$ (range $35-62 \%)$.

Before administration of the glucose load, seven subjects (one male, six female) received for 8-21 d a diet providing $3.96 \pm 0.56 \mathrm{MJ} / \mathrm{d}$. Before administration of the lipid load, four female subjects received $2 \cdot 94 \mathrm{MJ} / \mathrm{d}$.

Hyperlipidaemic group. Eleven subjects with mixed-type hyperlipidaemia (eight male, three female), average age 52 years (range $34-63$ ), were studied. The mean body-weight was $6 \mathrm{I} \mathrm{kg}$ (range $52 \cdot 8-72$ ) exceeding their ideal body-weight by $6 \%$ (range -2 to $+2 \cdot 7$ ). Their previous diet had provided daily $7 \cdot 3 \pm 1 \cdot 5 \mathrm{I} \mathrm{MJ} ; 74 \pm$ $10.4 \mathrm{~g}$ protein; $73 \pm 14.5 \mathrm{~g}$ fat.

The glucose load was administered to four subjects (three male, one female) after $2 \mathrm{I} \mathrm{d}$ on a diet providing daily $5.7 \pm 0.5 \mathrm{MJ} ; 74 \pm 6.6 \mathrm{~g}$ protein; $67 \pm \mathrm{I} \cdot 3 \mathrm{~g}$ fat. Seven subjects (five male, two female) were given the load after being given a diet providing $3.3 \mathrm{MJ} / \mathrm{d}$ for $2 \mathrm{I} \mathrm{d}$.

\section{Experimental procedure}

At 08.00 hours after $\mathrm{I}_{2}-\mathrm{I}_{4} \mathrm{~h}$ fasting, subjects rested for $\mathrm{I}_{5} \mathrm{~min}$ and gas-exchange measurements were done. A blood sample was taken at 08.30 hours. At 09.00 hours, a load of I $\mathrm{g}$ glucose $/ \mathrm{kg}$ ideal body-weight or $0.5 \mathrm{~g}$ oil (peanut or rapeseed) $/ \mathrm{kg}$ actual body-weight was administered orally. Blood samples were taken 45 and $120 \mathrm{~min}$ after the glucose load, and 150 and $210 \mathrm{~min}$ after the oil load. 


\section{Analytical procedures}

Lipid metabolites were separated by agarose gel electrophoresis by the method of Lees \& Hatch ( 1963 ) modified by Noble (1968). TL content was estimated by the colorimetric method of Zöllner \& Kirsch (1962). FFA levels were estimated using the method of Duncombe (1963, I964) and TG levels by the method of Schmidt $\&$ von Dahl (I968). $\beta$-HOB and AcAc levels were estimated by the enzymic method of Williamson, Mellanby \& Krebs (1962).

The amounts of glucose metabolites were estimated as follows: glucose by the glucose-oxidase method of Keston ( $195^{6}$ ), lactate and pyruvate by the enzymic method of Hohorst, Kreutz \& Bücher (1959) using the neutralized filtrate obtained after deproteinization with $10 \%$ perchloric acid ( $1 \mathrm{ml}$ perchloric acid: $2 \mathrm{ml}$ plasma), alanine by the method of Pfleiderer (1965), and free glycerol by the method of Schmidt \& von Dahl (r968).

Respiratory exchange was determined using the technique of Tremolières, Dontcheff \& Huot (1966), in which $\mathrm{CO}_{2}$ output was estimated by a weighing method.

\section{Statistical analysis}

Results are given as mean and standard error of the mean after verifying that the values have a 'normal' or 'log-normal' distribution (Lowy \& Manchon I968-9). The between-group variation was determined using the ' $F$ ' test (Lowy \& Manchon Ig68-9).

RESULTS

Plasma levels after $12 \mathrm{~h}$ fasting. Table $\mathrm{I}$ indicates that in obese subjects given a 'spontaneous' reducing diet $(5 \cdot 7 \pm 0.9 \mathrm{MJ} / \mathrm{d})$ there was a significant increase in TG, FFA, $\beta$-HOB and AcAc levels compared with those of normal subjects. Hyperlipidaemic subjects given a diet providing more energy $(7 \cdot 3 \pm \mathrm{I} \cdot 5 \mathrm{MJ} / \mathrm{d})$ than that of the obese group but less than that of the normal group, were found to have a higher level of TL, TC, TG, FFA but not of ketone bodies.

Effect of reduction of energy intake in obese subjects compared to that in hyperlipidaemic subjects. Table 2 shows that after $2 \mathrm{I} d$ on a diet providing $3.96 \pm 0.56 \mathrm{MJ} / \mathrm{d}, \beta$-HOB and AcAc levels of obese subjects increased, TL levels decreased while TC and TG levels remained unchanged. The mean FFA level increased but the variation was not statistically significant. In the hyperlipidaemic subjects given a diet providing $3.3 \mathrm{MJ} / \mathrm{d}$, there was a significant decrease in TL, TC, TG and FFA levels. There was no increase in the plasma levels of $\beta$-HOB or AcAc.

These results suggest an inability of the adipose tissue of the hyperlipidaemic group to mobilize its FA on a reduced diet, and to control the level of plasma lipoprotein on a higher energy intake. The reverse occurs in 'constitutionally' obese subjects, and can be related to the rapid reduction in respiratory quotient (RQ) found in these subjects after a $12 \mathrm{~h}$ fast (Table 5 ). Our thesis is that adipose tissue failed in its storage and mobilization functions in the hyperlipidaemic group, these functions being augmented in the obese. 
Table I. Amounts of lipid and glucose metabolites in plasma of eleven normal, six 'constitutionally' obese and eleven hyperlipidaemic subjects after $a \mathrm{I} 2 \mathrm{~h}$ fast

(Mean values with their standard errors; no. of subjects in parentheses)

\begin{tabular}{|c|c|c|c|c|c|c|}
\hline & \multicolumn{2}{|c|}{$\begin{array}{l}\text { Normal } \\
\quad(\mathbf{I} \text { I) }\end{array}$} & \multicolumn{2}{|c|}{$\begin{array}{l}\text { Obese } \\
(6)\end{array}$} & \multicolumn{2}{|c|}{$\begin{array}{l}\text { Hyperlipidaemic } \\
\text { (I I) }\end{array}$} \\
\hline & Mean & $\mathrm{SE}$ & Mean & SE & Mean & $\mathrm{SE}$ \\
\hline \multicolumn{7}{|l|}{ Plasma metabolite } \\
\hline Total lipid (g/l) & $7 \cdot 66$ & 0.41 & $7 \cdot \circ 3$ & $0.47 \mathrm{NS}$ & II 5 I & $0.66 * *$ \\
\hline $\begin{array}{l}\text { Total cholesterol } \\
(\mathrm{mmol} / \mathrm{l})\end{array}$ & $5 \cdot 18$ & 0.22 & 4.69 & $0.34 \mathrm{NS}$ & $8 \cdot 24$ & $0.4 I^{* * *}$ \\
\hline Triglycerides $(\mathrm{g} / \mathrm{l})$ & I'I I & $0.1 \mathrm{I}$ & $I \cdot 8 I$ & $0.11 *$ & $2 \cdot 79$ & $0.22 * *$ \\
\hline $\begin{array}{l}\text { Free fatty acids } \\
(\mu \text { equiv. } / 1)\end{array}$ & 652 & 63 & 1050 & $219^{* *}$ & 1330 & I $88 * *$ \\
\hline $\begin{array}{c}\beta \text {-hydroxybutyrate } \\
(\mu \mathrm{mol} / \mathrm{l})(\beta \text {-HOB })\end{array}$ & 164 & 25 & $5^{68}$ & $54^{* *}$ & I 34 & 2 INS \\
\hline $\begin{array}{l}\text { Acetoacetate }(\mu \mathrm{mol} / 1) \\
\quad(\text { AcAc) }\end{array}$ & $23 \cdot 1$ & $7 \cdot 6$ & 119 & II** & $31 \cdot 9$ & $5 \cdot 7 \mathrm{NS}$ \\
\hline$\beta$-HOB : AcAc & $7 \cdot 3$ & $I \cdot 2$ & 4.75 & $0.63 *$ & $4 \cdot 19$ & $0.13^{*}$ \\
\hline Glucose $(\mathrm{mmol} / \mathrm{l})$ & $5 \cdot 36$ & 0.21 & $4 \cdot 60$ & $0.89 \mathrm{NS}$ & $5 \cdot 10$ & $0.24 \mathrm{NS}$ \\
\hline Lactate $(\mathrm{mmol} / \mathrm{l})(\mathrm{L})$ & $I \cdot 529$ & 0.165 & $I \cdot 424$ & $0.170 \mathrm{NS}$ & $I \cdot 600$ & $0.13 I N S$ \\
\hline Pyruvate $(\mu \mathrm{mol} / \mathrm{l})(\mathrm{P})$ & $64 \cdot 2$ & $4 \cdot 3$ & $6 r \cdot 9$ & $6 \cdot 4 \mathrm{NS}$ & $74 \cdot 2$ & $7 \cdot 5 \mathrm{NS}$ \\
\hline$L: P$ & 23.8 & $2 \cdot 4$ & $23 \cdot 6$ & $2 \cdot 2 \mathrm{NS}$ & $2 \mathrm{I} \cdot 6$ & $\mathrm{I} \cdot 7 \mathrm{NS}$ \\
\hline Alanine $(\mu \mathrm{mol} / \mathrm{l})$ & 563 & 71 & 780 & 186NS & 627 & $84 \mathrm{NS}$ \\
\hline
\end{tabular}

Table 2. Effects of reducing energy intake for $2 \mathrm{x} d$, on levels of lipid and glucose metabolites in plasma of seven mixed-type hyperlipidaemic and seven 'constitutionally' obese subjects $\uparrow$

(Mean values with their standard errors)

\begin{tabular}{|c|c|c|c|c|c|c|c|c|}
\hline \multirow[t]{3}{*}{ Energy intake $(\mathrm{MJ} / \mathrm{d})$} & \multicolumn{4}{|c|}{$\begin{array}{l}\text { Hyperlipidaemic } \\
\qquad 3 \cdot 3\end{array}$} & \multicolumn{4}{|c|}{$\begin{array}{c}\text { Obese } \\
3.96 \pm 0.56\end{array}$} \\
\hline & \multicolumn{2}{|c|}{ Day o } & \multicolumn{2}{|c|}{ Day 2 I } & \multicolumn{2}{|c|}{ Day o } & \multicolumn{2}{|c|}{ Day 2 I } \\
\hline & Mean & SE & Mean & SE & Mean & $\mathrm{SE}$ & Mean & $\mathrm{SE}$ \\
\hline Plasma metabolite & & & & & & & & \\
\hline Total lipid $(g / 1)$ & ro.96 & 0.58 & 8.69 & $0.42 * *$ & $7 \cdot 5 \mathrm{I}$ & 0.26 & $5 \cdot 63$ & $0.26 * *$ \\
\hline $\begin{array}{l}\text { Total cholesterol } \\
(\mathrm{mmol} / \mathrm{l})\end{array}$ & $8 \cdot 00$ & 0.52 & $5 \cdot 83$ & $0 \cdot 3^{6 * *}$ & $5^{* 21}$ & 0.29 & 4.69 & $0.29 \mathrm{NS}$ \\
\hline Triglycerides (g/l) & $2 \cdot 66$ & 0.22 & $1 \cdot 92$ & $0.32 * *$ & $I \cdot 6 I$ & 0.17 & I.54 & $0.17 \mathrm{NS}$ \\
\hline $\begin{array}{l}\text { Free fatty acids } \\
(\mu \text { equiv. } / 1)\end{array}$ & I $55 \mathrm{I}$ & 322 & 650 & $122 *$ & 998 & 240 & 1600 & $240 N S$ \\
\hline $\begin{array}{r}\beta \text {-hydroxybutyrate } \\
(\beta-\mathrm{HOB})(\mu \mathrm{mol} / 1)\end{array}$ & $x 46$ & 22 & 149 & ${ }_{5} \mathrm{NS}$ & $3^{62}$ & 65 & 733 & $65 * *$ \\
\hline $\begin{array}{l}\text { Acetoacetate (AcAc) } \\
(\mu \mathrm{mol} / 1)\end{array}$ & 40.9 & $7 \cdot 6$ & $5 \mathrm{I} \cdot 0$ & $9 \cdot 7 \mathrm{NS}$ & 57 & 16 & 145 & $16 * *$ \\
\hline$\beta-\mathrm{HOB}: \mathrm{AcAc}$ & $3 \cdot 5$ & 0.47 & $2 \cdot 9$ & $0.4 \mathrm{NS}$ & $6 \cdot 3$ & $1 \cdot 3$ & $5 \cdot 0$ & 0.5 \\
\hline Glucose $(\mathrm{mmol} / \mathrm{l})$ & $5 \cdot 27$ & 0.27 & 5.00 & $0.24 \mathrm{NS}$ & 5.05 & 0.27 & $4 \cdot 77$ & $0.27 \mathrm{NS}$ \\
\hline Lactate $(\mathrm{mmol} / \mathrm{l})$ & $\mathrm{I} \cdot 559$ & 0.132 & $I \cdot 034$ & $0.065 \mathrm{NS}$ & $1 \cdot 315$ & 0.161 & $1 \cdot 151$ & $0.161 \mathrm{~N}$ \\
\hline Pyruvate $(\mu \mathrm{mol} / \mathrm{l})$ & $70 \cdot 7$ & $9 \cdot 6$ & $65 \cdot 3$ & $5 \cdot 0 \mathrm{NS}$ & $73 \cdot 4$ & $4 \cdot 6$ & $79 \cdot 6$ & $4 \cdot 6 \mathrm{NS}$ \\
\hline
\end{tabular}

NS, not significant; $* P<0.05 ; * * P<0.01$.

+ For details of previous diets see p. 274 . 
Table 3. Effects of administration of a glucose load (I g/kg ideal body-weight) on levels of lipid and glucose metabolites in plasma of eleven normal $(N)$, ten mixed-type hyperlipidaemic $(H)$ and six 'constitutionally' obese $(O)$ subjects 0,45 and 120 min after loading

(Mean values with their standard errors)

\begin{tabular}{|c|c|c|c|c|c|c|c|}
\hline & & \multicolumn{6}{|c|}{ Sampling time after administration of load (min) } \\
\hline & & \multicolumn{2}{|c|}{$\circ$} & \multicolumn{2}{|c|}{45} & \multicolumn{2}{|c|}{120} \\
\hline & & Mean & $\mathrm{SE}$ & Mean & SE & Mean & SE \\
\hline $\begin{array}{l}\text { Total cholesterol } \\
(\mathrm{mmol} / \mathrm{l})\end{array}$ & $\begin{array}{l}\mathrm{H} \\
\mathrm{O} \\
\mathrm{N}\end{array}$ & $\begin{array}{l}8 \cdot 24 \\
4 \cdot 69 \\
5 \cdot 18\end{array}$ & $\begin{array}{l}0.42 \\
0.35 \\
0.22\end{array}$ & $\begin{array}{l}7 \cdot 93 \\
4 \cdot 64 \\
4 \cdot 92\end{array}$ & $\begin{array}{l}0.44 \mathrm{NS} \\
0.34 \mathrm{NS} \\
0.23 \mathrm{NS}\end{array}$ & $\begin{array}{l}7 \cdot 64 \\
4 \cdot 53 \\
4 \cdot 82\end{array}$ & $\begin{array}{l}0.42 \mathrm{NS} \\
0.35 \mathrm{NS} \\
0.22 \mathrm{NS}\end{array}$ \\
\hline Triglycerides $(\mathrm{g} / \mathrm{l})$ & $\begin{array}{l}\mathrm{H} \\
\mathrm{O} \\
\mathrm{N}\end{array}$ & $\begin{array}{l}2 \cdot 79 \\
I \cdot 8 I \\
I \cdot I I\end{array}$ & $\begin{array}{l}0.22 \\
0.11 \\
0.11\end{array}$ & $\begin{array}{l}2.53 \\
1.65 \\
0.95\end{array}$ & $\begin{array}{l}0.12 \mathrm{NS} \\
0.09 * \\
0.12 * *\end{array}$ & $\begin{array}{l}2.52 \\
1.64 \\
0.79\end{array}$ & $\begin{array}{l}0.12 \mathrm{NS} \\
0.09 \mathrm{NS} \\
0.12 * *\end{array}$ \\
\hline $\begin{array}{l}\text { Free fatty acids } \\
(\mu \text { equiv. } / 1)\end{array}$ & $\begin{array}{l}\mathbf{H} \\
\mathrm{O} \\
\mathrm{N}\end{array}$ & $\begin{array}{r}1330 \\
1050 \\
652\end{array}$ & $\begin{array}{r}188 \\
219 \\
63\end{array}$ & $\begin{array}{r}1003 \\
467 \\
451\end{array}$ & $\begin{array}{c}286 \mathrm{NS} \\
87^{* *} \\
55^{* *}\end{array}$ & $\begin{array}{r}1006 \\
375 \\
330\end{array}$ & $\begin{array}{c}298 \mathrm{NS} \\
87 \mathrm{NS} \\
55^{* *}\end{array}$ \\
\hline $\begin{array}{l}\beta \text {-hydroxybutyrate } \\
(\mu \mathrm{mol} / \mathrm{l})\end{array}$ & $\begin{array}{l}\mathrm{H} \\
\mathrm{O} \\
\mathrm{N}\end{array}$ & $\begin{array}{l}\text { I34 } \\
568 \\
\text { I64 }\end{array}$ & $\begin{array}{l}21 \cdot 3 \\
53 \cdot 7 \\
24 \cdot 6\end{array}$ & $\begin{array}{l}134 \\
573 \\
135\end{array}$ & $\begin{array}{l}32 \cdot 8 \mathrm{NS} \\
53 \cdot 7 \mathrm{NS} \\
27 \cdot 7 \mathrm{NS}\end{array}$ & $\begin{array}{l}123 \\
330 \\
150\end{array}$ & $\begin{array}{l}17 \cdot 8 \mathrm{NS} \\
60 \cdot 7^{*} \\
\text { I } 8 \cdot 2 \mathrm{NS}\end{array}$ \\
\hline $\begin{array}{l}\text { Acetoacetate } \\
(\mu \mathrm{mol} / 1)\end{array}$ & $\begin{array}{l}\mathbf{H} \\
\mathrm{O} \\
\mathrm{N}\end{array}$ & $\begin{array}{l}31 \cdot 9 \\
11 \cdot 9 \\
23 \cdot 1\end{array}$ & $\begin{array}{c}5 \cdot 70 \\
\text { I } 1 \cdot 3 \\
7 \cdot 53\end{array}$ & $\begin{array}{l}\text { I } 5.4 \\
\text { I32 } \\
\text { I I.9 }\end{array}$ & $\begin{array}{c}2.54^{*} \\
\text { I } \cdot 3 \mathrm{NS} \\
2.08 \mathrm{NS}\end{array}$ & $\begin{array}{c}9 \cdot 89 \\
93 \\
8 \cdot 6\end{array}$ & $\begin{array}{l}0.80^{*} \\
13.4 * \\
1.21 \mathrm{NS}\end{array}$ \\
\hline Glucose $(\mathrm{mmol} / \mathrm{l})$ & $\begin{array}{l}\mathrm{H} \\
\mathrm{O} \\
\mathrm{N}\end{array}$ & $\begin{array}{l}5 \cdot 10 \\
4 \cdot 55 \\
5 \cdot 36\end{array}$ & $\begin{array}{l}0.25 \\
0.91 \\
0.21\end{array}$ & $\begin{array}{l}7 \cdot 88 \\
7 \cdot 38 \\
7 \cdot 71\end{array}$ & $\begin{array}{l}0.62 * * \\
0.91 * * \\
0.59 * *\end{array}$ & $\begin{array}{l}5 \cdot 82 \\
6 \cdot 55 \\
5 \cdot 54\end{array}$ & $\begin{array}{l}0.46 * \\
0.91 \mathrm{NS} \\
0.22 * *\end{array}$ \\
\hline
\end{tabular}

Effects of administration of a glucose load. Table 3 shows that in hyperlipidaemic subjects, compared with obese and normal subjects, administration of a glucose load did not produce a significant decrease in TG or FFA levels but did produce a decrease in AcAc levels. In obese subjects under similar hyperglycaemic conditions there was a decrease in plasma TG and FFA levels.

Effects of administration of an oil (TG) load. Table 4 shows that in obese subjects, there was no significant increase in TG levels compared with normal subjects, but glycerol levels were increased and glycaemia was reduced.

Therefore, with this energy intake, the obese subject has a greater ability to store FA, i.e. remove FA from plasma.

Effects of a reduced energy intake and of glucose load on respiratory exchanges. Table 5 shows that in obese subjects given a low-energy diet, RQ was reduced more rapidly than in hyperlipidaemic patients. In all subjects energy expenditure was the same, and a glucose load produced an increased glucose oxidation when RQ was lowered by reducing energy intake.

\section{DISCUSSION}

Figs. I and 2 summarize the results and suggestions for a physiopathological explanation for the information obtained. 


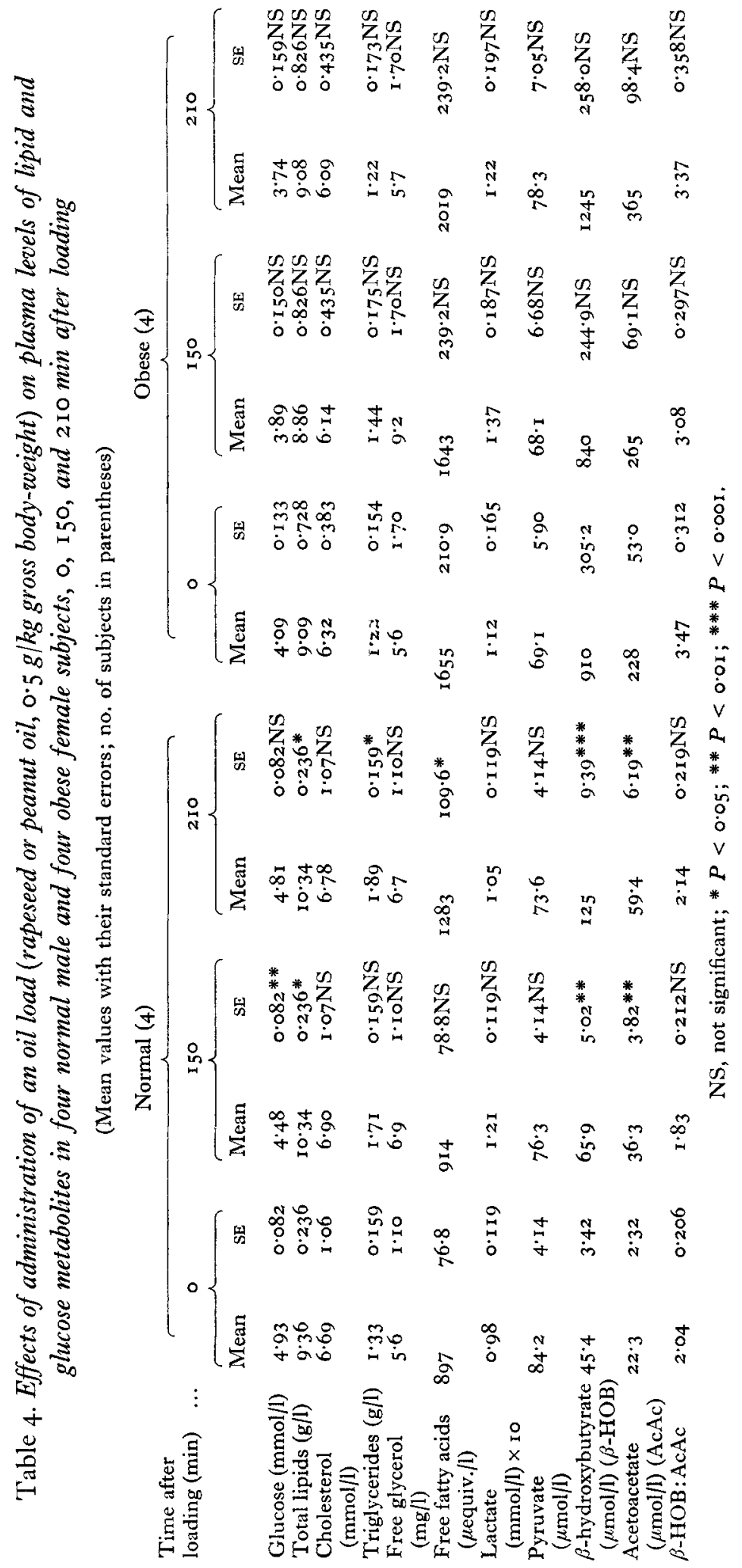


Vol. 32

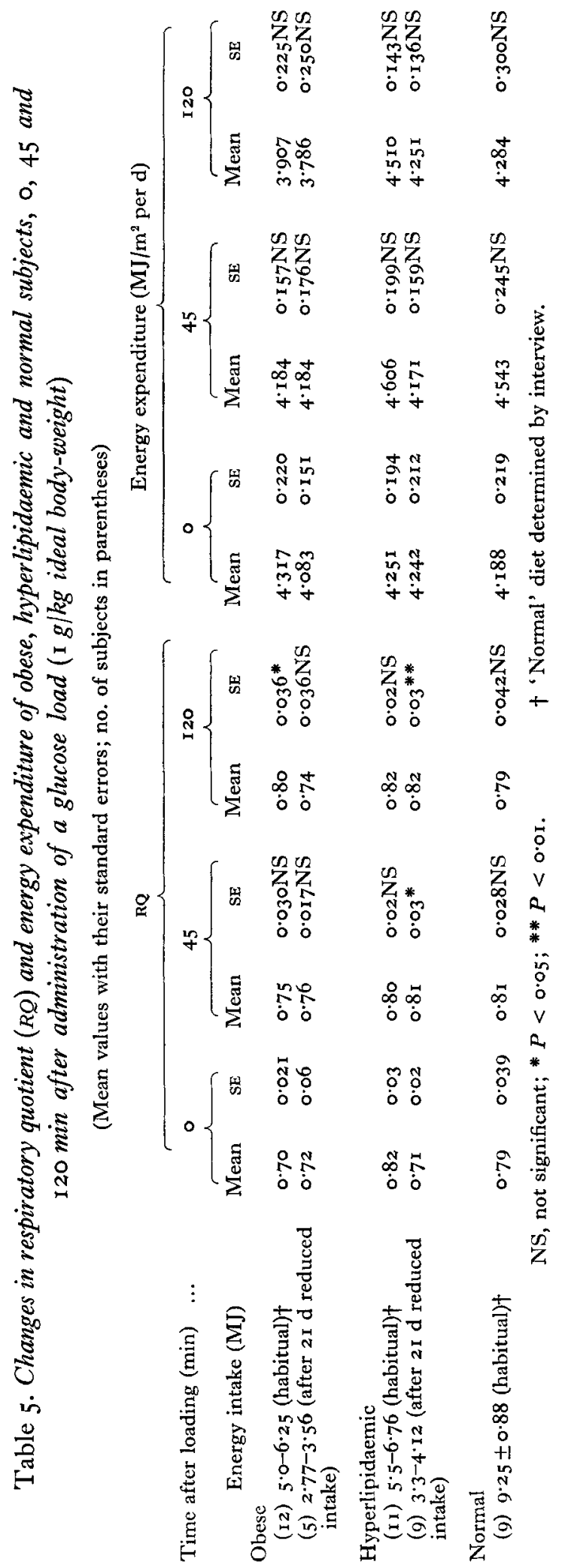




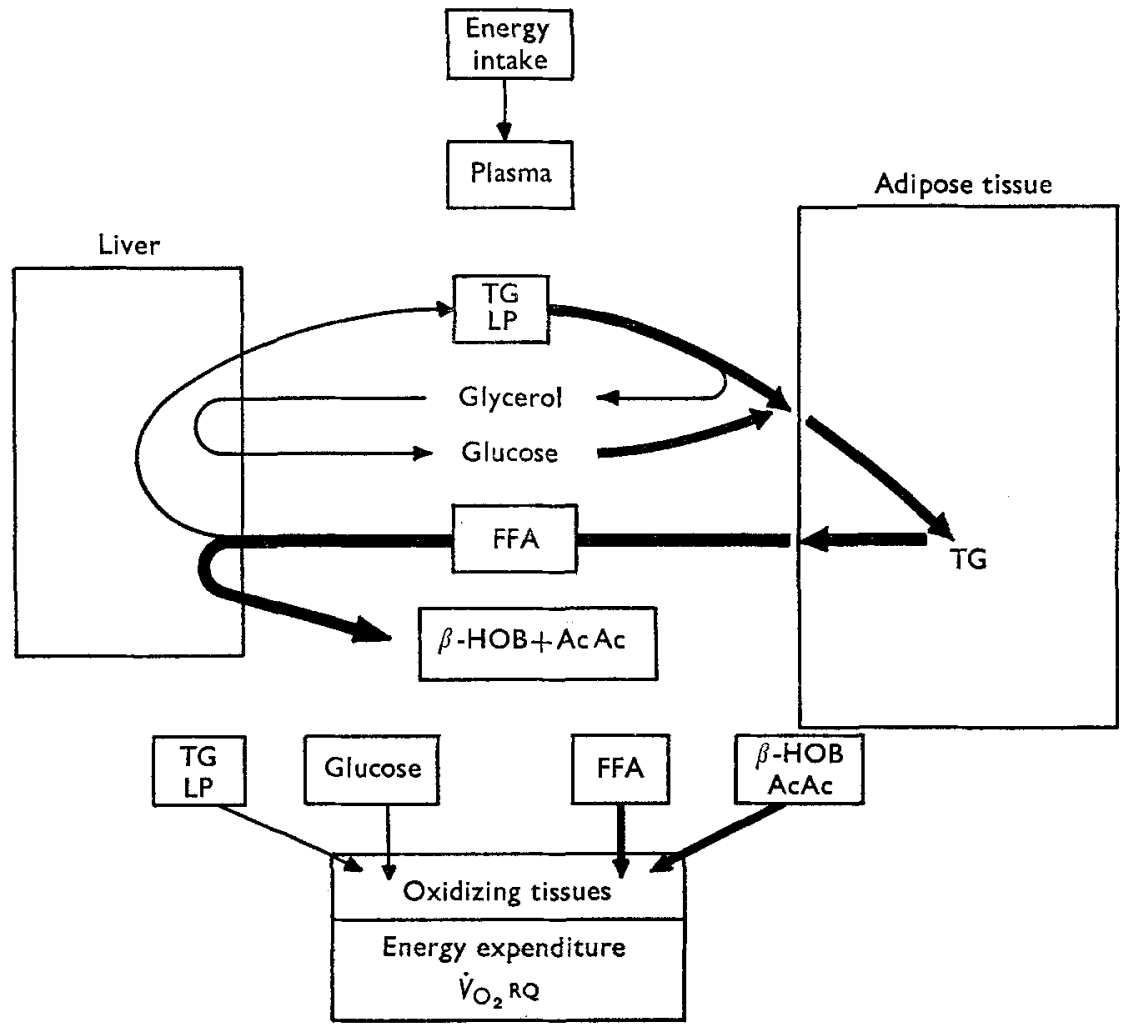

Fig. I.* Administration of a triglyceride (TG) load $(0.5 \mathrm{~g} / \mathrm{kg})$ results in no change in TG levels but a reduction in glucose levels. Administration of a glucose load produces a decrease in TG levels. Reducing energy intake resulted in an increase in free fatty acids (FFA) $\beta$ hydroxybutyrate $(\beta-\mathrm{HOB})$ and acetoacetate $(\mathrm{AcAc})$ levels. $\Rightarrow$, enhancement of pathway; LP, lipoprotein, $\dot{V}_{\mathrm{O}_{2}}$, oxygen consumption; RQ, respiratory quotient. * From Trémolières (I 973).

The results suggest that 'constitutionally' obese subjects at the energy level intake studied have an increased ability (a) to oxidize FA, particularly ketone bodies; (b) to store $\mathrm{FA}$ after receiving a TG load, therefore reducing glycaemia, and $(c)$ to store plasma TG under conditions of hyperglycaemia.

In mixed-type hyperlipidaemic subjects, the opposite situation was found. Hyperlipidaemia was reduced when energy intake was reduced, and there was a deterioration of the process of FA mobilization from adipose tissue under fasting conditions and, as a result, an inability to generate FA metabolites in the form of ketone bodies. The increased ability of obese subjects to increase levels of ketone bodies under fasting conditions is subject to controversy.

Cahill, Owen \& Morgan (1968) found that in ten obese subjects receiving only $1500 \mathrm{ml}$ water $/ \mathrm{d}$ for 5 weeks and expending $7.9 \mathrm{MJ}$ energy $/ 24 \mathrm{~h}(95 \%$ derived from FA), the plasma levels of $\beta$-HOB, AcAc and FFA (nmol/ml) were 633 , in Io and 2037 respectively. The rate of ketosis is six times higher than the values we obtained, but the $\beta$-HOB: AcAc ratio is the same. 


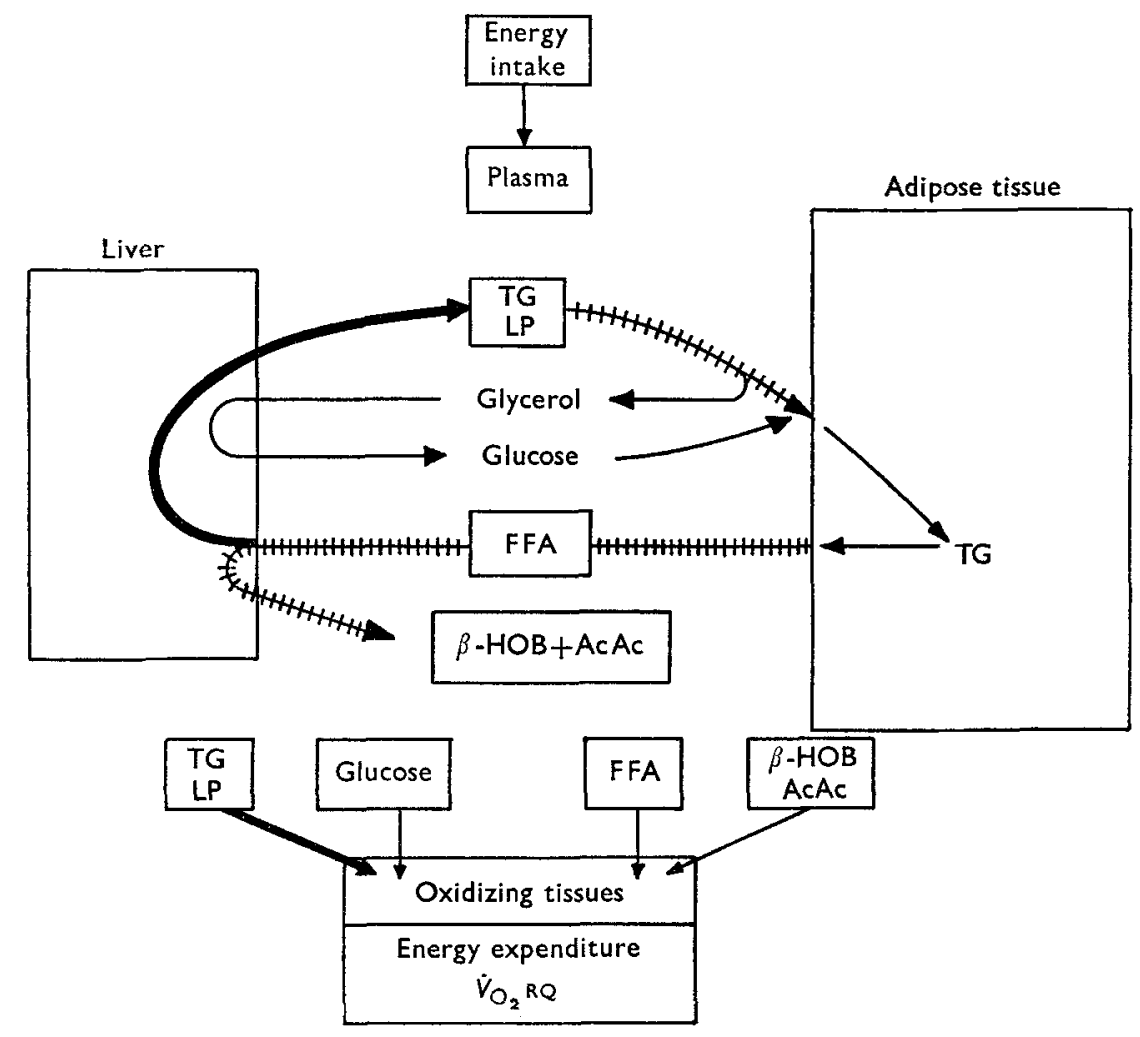

Fig. 2.* Administration of a glucose load ( $\mathrm{r} / \mathrm{kg}$ ideal body-weight) produced no reduction in triglycerides (TG) or free fatty acid (FFA) levels. Reducing energy intake resulted in a reduction in TG and total lipid levels but no increase in FFA or $\beta$-hydroxybutyrate $(\beta$-HOB) and acetoacetate (AcAc) levels. $\rightarrow$, enhancement of the pathway; $\# \perp \rightarrow$, diminution of the pathway; LP, lipoprotein. $\hat{V}_{\mathrm{O}_{2}}$, oxygen consumption; RQ, respiratory quotient. * From Trémolières (1973).

Kekwick \& Pawan (I957) reported contradictory results from experiments with ten obese subjects given a diet providing $4.2 \mathrm{MJ} / \mathrm{d}(90 \%$ derived from $\mathrm{FA}, 5 \%$ from glucose). Ketosis was apparently much slower and much lower than in normal subjects. After intravenous infusion of $\beta$-HOB ( $30 \mathrm{mg} / \mathrm{kg}$ body-weight) their ability to oxidize ketone bodies was unchanged. Either the type of obesity, or the composition of the pre-experimental diet may have been responsible for these different observations.

The effect of administration of a glucose load in lowering serum TG levels apparently depends on numerous factors. Waterhouse \& Kemperman (1966) and Waterhouse, Baker \& Rostami (1969) reported that an intravenous infusion of $0.5 \mathrm{~g}$ glucose $/ \mathrm{kg}$ body-weight resulted in a reduction of $65 \%$ in the oxidation of FA to $\mathrm{CO}_{2}$. Barter \& Nestel (I972) and Barter, Nestel \& Carrol (r972) found that plasma TG levels decreased after glucose ingestion and that there was an increase in FA turnover when the glucose intake was the same as the energy expenditure. The lower plasma TG levels after glucose ingestion could be related to a temporary change in the equilibrium between the inflow and outflow of FA in adipose tissue. 
Tamir, Grant, Fosbrooke, Segall \& Lloyd (1968) were unable to confirm this in experiments with four men who had fasted overnight.

A reduction in blood glucose levels after administration of a TG (medium chain length FA) load, was reported by Debry, Laurent, Drouin, Méjean, Gonand \& Cherrier (I969) and by Tamir et al. (I968) with I $\mathrm{g} / \mathrm{kg}$ (- 13 to $-23 \mathrm{~m} / \mathrm{gl}$ ).

\section{REFERENCES}

Barter, P. J. \& Nestel, P. J. (1972). F. Lipid Res. I3, 483.

Barter, P., Nestel, P. \& Carrol, K. (1972). Metabolism 21, I 7 .

Cahill, G. F. Jr, Owen, O. E. \& Morgan, A. P. (I968). In Advances in Enzyme Regulation Vol. 6, p. 143 [J. Weber, editor]. London: Pergamon Press.

Debry, G., Laurent, J., Drouin, P., Méjean, L., Gonand, J. \& Cherrier, P. (1969). Fournées Diabétol., Hôtel-Dieu, p. 225.

Duncombe, W. G. (1963). Biochem. F. 88, 7 .

Duncombe, W. G. (1964). Clinica chim. Acta 9, 122.

Geigy, J. R. (1959). Statist. Bull. Metropolitan Life Insurance Co. Vol. 40.

Hohorst, H. J., Kreutz, F. H. \& Bücher, Th. (1959). Biochem. Z. 332, 18.

Kekwick, A. \& Pawan, G. L. S. (1957). Metabolism 6, 447.

Keston, A. S. (1956). Proc. I 29 th Meet. Am. Chem. Soc., Dallas, p. 3 1o. Washington, DC: American Chemical Society Publications.

Lees, R. S. \& Hatch, F. T. (1963). F. Lab. clin. Med. 6r, 5 I 8.

Lowy, R. \& Manchon, Ph. (1968-9). In Eléments de Statistiques Appliqués à la Biologie, Vol. 1-3. Paris: Olivetti.

Noble, R. P. (1968). 7. Lipid Res. 9, 693.

Pfleiderer, G. (1965). In Methods of Enzyme Analysis, p. 378 [H. U. Bergmeyer, editor]. Weinheim, W. Germany: Verlag Chemie GmbH.

Schmidt, F. H. \& von Dahl, K. (1968). Z. klin. Chem. 6, $1_{5} 6$.

Tamir, I., Grant, D. B., Fosbrooke, A. S., Segall, M. M. \& Lloyd, J. K. (1968). F. Lipid Res. 9, 66 . Trémolières, J. (1973). Proc. Nutr. Soc. 32, 169.

Trémolières, J., Dontcheff, L. \& Huot, A. (1966). \%. Physiol., Paris 58, 655.

Waterhouse, C. \& Kemperman, J. H. (1966). F. Lab. clin. Med. 68, 250.

Waterhouse, C., Baker, N. \& Rostami, H. (1969). F. Lipid Res. 10, 487.

Williamson, D. H., Mellanby, J. \& Krebs, H. A. (1962). Biochem. F. 82, 90.

Zöllner, N. \& Kirsch, K. (1962). Z. ges. exp. Med. 135, 545. 